\section{Production of Kojic Acid by Aspergillus effusus Tiraboschi}

IN 1942 Wilkins and Harris ${ }^{1}$ reported that culture media on which the mould Aspergillus effusus Tiraboschi (National Collection of Type Cultures, No. 973) had grown inhibited the growth of $B$. coli and Staph. aureus. It has been found that, under cultural conditions to be described, the whole of the antibacterial activity can be attributed to the production of kojic acid. Owing to the weakness of its antibacterial properties this substance is not generally regarded as an antibiotic; its detection as such was due to its relatively high concentration in the culture fluid. Attention is directed here to kojic acid as an antibiotic because it is a common product of mould metabolism and may account for the inhibitory properties of a number of moulds not yet investigated in detail. Recognition of this possibility may prove time-saving to other workers.

Kojic acid is stated by Yabuta ${ }^{2}$ to be produced in a high yield from various carbohydrate sources by Aspergillus oryzo, albus, candidus and nidulans. It was obtained by Birkinshaw et al. ${ }^{3}$ from Aspergillus parasiticus and Penicillium daleo Zaleski. The latter authors deduced its production also by $A$. effusus Tiraboschi, A. tamari and $A$. flaves from the production of a strong wine-red colour on treating the crude medium with ferric chloride; but it should be noted that the mould products claviformin (produced by at least four fungal species) and aspergillic acid give a similar red colour with ferric chloride. The literature of kojic acid, up to 1934 , has been reviewed by Barham and Smits ${ }^{4}$, who mention its antibacterial properties.

The mould was grown at $24^{\circ} \mathrm{C}$. in Erlenmeyer flasks on a medium of the following composition : maltose 40 gm., peptone 10 gm., malt extract 26 c.c., water 1 litre. The antibacterial activity of the medium, measured by the plate and cylinder method against Staph. aureus, reached a maximum at 12-14 days, thereafter diminishing rapidly. At that time yields of kojic acid averaged 8-9 gm. cer litre.

Tested by the dilution method, kojic acid completely inhibited the growth of a strain of the follow. ing bacteria at the concentration shown :

$$
\begin{aligned}
& >1: 400<1: 800 \text { Proteus, Salm. enteritidis, Bact. coli. } \\
& >1: 800<1: 1600 \text { Salm. typhi, Staph. pyogenes. } \\
& >1: 1600<1: 3200 \text { Ps. pyocyanea (2 strains). } \\
& >1: 3200<1: 6400 \text { P8. pyocyanea (2 strains). }
\end{aligned}
$$

Unlike that of many other antibacterial substances, its potency was little affected by the number of bacteria present. A thousandfold increase in the size of the inoculum made little or no alteration in the inhibitory titre. Neither was the antibacterial activity reduced after incubation for three hours at $37^{\circ} \mathrm{C}$. in 50 per cent serum.

For testing toxicity to animal tissues, solutions of kojic acid were neutralized with sodium hydroxide to $p \mathrm{H} 6.8$ (which does not diminish the antibacterial activity of the solution). The toxicity to cells in vitro was estimated by its effect on human leucocytes ${ }^{5}$. In a 1:100 solution the cells' became sluggish or stationary in half an hour and were nearly all dead in three hours. In 1:200 the movement of the majority was arrested in two hours but the cells did not die. The preparation in $1: 400$ did not differ significantly from control preparations. Dr. R. W. Ross informs us that a 1 : 400 solution did not interfere with phagocytosis by human leucocytes.

Sodium kojate produced characteristic signs when injected into mice by any route in a sufficiently large dose. The mouse became prostrate, the legs and tail stretched out stiffly and the breathing slow and laboured; the coat was not roughened. After the largest doses there was slight irregular twitching of muscle groups and a lethal dose produced convulsions before death. The duration of sickness was proportional to the size of the dose, and even after prostration lasting for two or three hours, recovery, if it occurred, was rapid and complete.

Friedemann ${ }^{6}$ described similar effects on dogs, rabbits and rats, and gave the toxic dose (intravenous) as $150 \mathrm{mgm}$. per $\mathrm{kgm}$. and the lethal dose as $1 \mathrm{gm}$. per $\mathrm{kgm}$. The figures for mice are of the same order. In mice weighing from 20 to $23 \mathrm{gm}$., 5 mgma. injected subcutaneously, intraperitoneally or intravenously usually produced signs of toxicity, and $30-40 \mathrm{mgm}$. killed; by mouth $20 \mathrm{mgm}$. was without effect, $40 \mathrm{mgm}$. produced illness and $80 \mathrm{mgm}$. killed.

M. A. JENNINGS.

T. I. WILLIAMS.

Sir William Dunn School of Pathology, University of Oxford. Jan. 24.

${ }^{1}$ Wilkins, W. H., and Harris, G. C. M., Brit. J. Exp. Path., 23, 166 (1942).

'Yabuta, J. Chem. Soc., 122, 939 (1922).

Birkinshaw, J. H., Charles, J. H. V., Lilly, C. H., and Raistrick, H., Trans. Roy. Soc. (B), 220, 127 (1931).

- Barham, H. N., and Smits, B. L., Trans. Kangsas Acad. Science, 37, 91 (1934).

s Abraham, E. P., Chain, E., Fletcher, C. M., Florey, H. W., Gardner,

A. D., Heatley, N. G., and Jennings, M.' A., Lancet, ii, i77 (1941), - Friedemann, T. E., Science, 80, 34 (1934).

\section{A Twenty-four Hour Pregnancy Test for Equines}

IN 1928 the Aschheim-Zondek Test for the diagnosis of human pregnancy in urine was introduced ${ }^{1}$. In 1930, B. Zondek proposed a modification of this test for the diagnosis of equine pregnancy in the blood and in the urine ${ }^{2}$. The blood test is only feasible, however, between the $42 \mathrm{nd}$ and $125 \mathrm{th}$ days of pregnancy, after which the equine gonadotropin disappears from the blood ${ }^{3}$.

These pregnancy tests are based upon the gonadotropic reactions which have been classified (1926-27) as follows':

Anterior pituitary reaction, I : cestrus reaction in the mouse and rat.

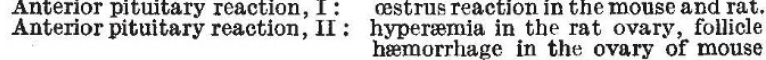
Anterior pituitary reaction, III : and rabbit (blood dot). : corpus luteum formation in the ovary of mouse, rat and rabbit.

Most characteristic is the follicle hæmorrhage appear-. ing (as anterior pituitary reaction II) in the ovary of the mouse and rabbit, which has since been used for the diagnosis of pregnancy in man and equines. The reliability of pregnancy tests, based upon the gonadotropic reaction, is about 99 per cent. The only disadvantage of these tests is the long reaction time required : 6 days for the rat, 5 days for the mouse and 2 days for the rabbit.

It has recently been demonstrated that a reliable diagnosis of human pregnancy may be carried out within twenty-four hours, using the hyperæmic reaction of the infantile rat ovary (anterior pituitary reaction II). The test is based on the fact that within twenty-four hours (sometimes even two to six hours) following the injection of human pregnancy urine, the ovaries of the infantile rat undergo a strong 